\title{
ENDOGENOUS SHOCKS IN CROATIAN UNEMPLOYMENT
}

\section{Ivan Novak*}

\begin{abstract}
Using the quantile regression approach this paper explores the nature of endogenous shocks in unemployment of Croatia during the period 2000Q1-2018Q4. Standard unit root tests give inconclusive results. Recent literature highlights the bias of unit root tests toward the null hypothesis. Considering the nonlinear nature of time series which may influence the standard unit root tests this paper uses a quantile auto-regression approach. Results confirm unemployment hysteresis in Croatia. Furthermore, there is an asymmetric behavior of endogenous shocks. Outcomes have important implications for policy, growth and development of the Croatian economy.
\end{abstract}

KEYWORDS: quantile regression, hysteresis, unemployment, Croatia

\section{INTRODUCTION}

Level of unemployment is one of the most important indicators of growth and development of the economy. Guidelines of the European Union underpinning the Europe 2020 Strategy for smart, sustainable and inclusive growth emphasize improving the labor market, boosting demand for labor, enhancing labor quality and fairness ${ }^{1}$. Unemployment is related with inability to earn income and lower quality of life burdening the individual and the society ${ }^{2}$. Among EU countries Croatia has a relatively high level of unemployment. In the first

\footnotetext{
Assistant Professor, Faculty of Economics and Business University of Zagreb; inovak1@ net.efzg.hr

1 https://eur-lex.europa.eu/legal-content/EN/TXT/?uri=CELEX:32018D1215, accessed on $09 / 09 / 2019$.

2 Bejaković, P.: Mjere za ublažavanje dugotrajne nezaposlenosti u Hrvatskoj. Političke analize, 9 (33-34) 2018, p. 36-43.
} 
quarter of 2014 Croatia has reached 17,6\% whereas higher rates of unemployment were present only in Greece $(27,1 \%)$ and Spain $(25,2 \%)$ (See appendix 1a). Consequently, the level of unemployment is an important issue regarding the growth and development of the Croatian economy.

Existing literature examines unemployment using two main approaches. One approach implies natural level of unemployment where changes in the level of unemployment are temporary and unemployment returns to its average value. The other approach implies presence of hysteresis where change in the level of unemployment is persistent and therefore new average level of unemployment is being established. This paper uses rather innovative technique of quantile regression analysis to examine the presence of hysteresis in the Croatian unemployment in the period 2000Q1.-2018Q4. Considering direction and persistence of endogenous shocks quantile regression analysis may offer additional insights regarding features of unemployment in Croatia.

The duration of unemployment decreases the probability of finding work and increases the affliction of labor market disturbance ${ }^{3}$ while almost half of the Croatian unemployment is long-term unemployment ${ }^{4}$. Therefore, the existence of hysteresis is an important issue concerning policy corrective measures. If the endogenous shocks in the level of unemployment do not have the tendencies to persist, the level of unemployment should revert to its mean value and if the shock persists affliction of the labor market disturbance may surpass the cost of the corrective measures.

Remaining of the paper is organized in five parts. Second part of paper provides literature overview of the research topic. Third part of the paper presents data and methodology. Fourth part of the paper is about results and short discussion. Finally, conclusion summarizes results of the paper and considers further policy implications.

\section{LITERATURE OVERVIEW}

Unemployment hysteresis was tested for 10 European countries in the period 2005Q1- 2017Q3. Time series were examined with linear and non-linear tests. ESTAR (Eng. exponential smoothing transitional autoregressive) and AESTAR (Eng. asymmetric exponential smoothing transitional autoregressive) models reveal hysteresis in Serbia and Macedonia while hysteresis was reject-

\footnotetext{
Kroft, K. et al:: Duration Dependence and Labor Market Conditions: Evidence from a Field Experiment, The Quarterly Journal of Economics, Volume 128, 3(1) 2013, p. 1123-1167.

4 Bejaković, P.: Mjere za ublažavanje dugotrajne nezaposlenosti u Hrvatskoj, Političke analize, 9 (33-34) 2018, p. 36-43. Preuzeto s https://hrcak.srce.hr/205960
} 
ed for Croatia, Greece, Bulgaria, Romania, Slovenia, Albania, Montenegro and Turkey ${ }^{5}$. Similar approach was used in the study examining the unemployment hysteresis for 31 European countries, USA and Japan. According to the results hysteresis was rejected for $60 \%$ of the examined countries and some countries were found to exhibit asymmetries and structural breaks ${ }^{6}$.

Using univariate and panel unit root tests and the structural break analysis unemployment hysteresis was tested for selected OECD countries and countries in transition in the period from 2000M1 to 2013M1. Hysteresis was confirmed for Bulgaria, Czech Republic, Estonia, Hungary, Latvia, Lithuania, Poland, Romania, Slovenia and Slovakia and rejected for Belgium, Denmark, Finland, Germany, Italy, Netherlands, Norway, Spain and Great Britain ${ }^{7}$. Furthermore, using panel stationary test with sharp and smooth breaks unemployment hysteresis was tested for five highly indebt countries of the European Union (Greece, Ireland, Italy, Portugal and Spain) in the period 1960.-2011. Hysteresis was confirmed only for Greece ${ }^{8}$. Testing for structural breaks and applying Fourier transformations 14 OECD countries were examined for hysteresis in the period from 1983Q1 to 2013Q3. Results were confirmed with tests robust to non-normal errors. Hysteresis was found in Italy, Japan, Portugal and Canada. Unemployment had mean reverting properties in Belgium, Denmark and Canada as well as France, Ireland, Luxemburg, Netherlands, UK, USA and Sweden once considering for structural breaks. Ireland was found to have the nonlinear form of unemployment with mean reverting properties. ${ }^{9}$

Allowing for correlation of unemployment among European countries and applying Fourier transformations study examines hysteresis for France, Italy, Germany, Great Britain and Spain in the period 1991-2015. Hysteresis was rejected only for $\operatorname{Spain}^{10}$. Similar approach was used to test the hysteresis for

5 Obradović, S. et al.: Are unemployment rates stationary for SEE10 countries? Evidence from linear and nonlinear dynamics, Zbornik Radova Ekonomskog Fakulteta u Rijeci, 36(2) 2018, p. 559-583.

6 Akdogan, K.: Unemployment hysteresis and structural change in Europe, Empir Econ, 53(4) 2017, p. 1415-1440.

7 Marjanovic, G.; Mihajlovic, V.: Analysis of Hysteresis in unemployment rates with structural breaks: the case of selected European countries, Inzinerine Ekonomika-Engineering Economics, 25(4) 2014, p. 378-386.

$8 \mathrm{Li}$, J. et al:: Unemployment hysteresis in PIIGS countries: a new test with both sharp and smooth breaks, The Singapore Economic Review, 62(05) 2017, p. 1165-1177.

9 Meng, M. et al.: Hysteresis in unemployment? Evidence from linear and nonlinear unit root tests and tests with non-normal errors, Empirical Economics, 53(4) 2017, p. 1399-1414.

10 Furuoka, F.: A new test for analysing hysteresis in European unemployment, Applied Economics Letters, 24(15) 2017, p. 1102-1106. 
Estonia, Latvia and Lithuania. According to FADF test (Fourier Augmented Dickey-Fuller) i SUR-FADF (extension of SUR-ADF test with Fourier transformations), Lithuania's unemployment was found to have mean reverting properties while endogenous shocks in Estonia and Latvia persisted. ${ }^{11}$ Fourier transformations were further applied for CEE countries and at least one of the applied tests rejected the hysteresis in each country except Hungary. ${ }^{12}$ Furthermore, according to bounded series unit root tests based on the SaidDickey-Fuller test and MZ statistics unemployment hysteresis was tested for Belgium, Finland, France, Ireland, Italy, Germany and Spain in the period 1965-2013. When considering structural breaks hysteresis was confirmed for all countries. ${ }^{13}$

Using fractional integration examination of the unemployment was done for Spain in the period 1986-2016. Results revealed asymmetries and persistence of endogenous shocks. Persistence was more present in times of downturn and less in expansion. ${ }^{14}$ Unemployment in Turkey was examined in the period 1988-2013. Results revealed integration equal to or higher than 1 emphasizing importance of the corrective policy. ${ }^{15}$ Croatian unemployment was examined in the period 2000-2015 exhibiting properties of fractionally integrated process. Results confirm weak stationarity, past period's dependence, long memory, mean reverting property and covariance stationarity. ${ }^{16}$ According to nonlinear multivariate singular spectrum modelling unemployment in Croatia has "partial hysteresis". Unemployment rate exhibits some properties of random walk natural unemployment hypothesis holds. Change in the unemployment rate seems to follow the business cycles repeated each 5-6 years. ${ }^{17}$ Another study using fractional integration was published examining CEE countries that joined the European Union in 2004. Results stress non-stationarity of unem-

11 Furuoka, F.: Mean reversion in unemployment: New findings from the Baltic tigers, Technological and Economic Development of Economy, 23(3) 2017, p. 462-482.

12 Dursun, G.: Unemployment Hysteresis in Central and Eastern European Countries: Further Evidence from Fourier Unit Root Tests, 2017, EconWorld2017@Rome Proceedings, Rome, Italy

13 Albulescu, C. T.; Tiwari, A. K.: Unemployment persistence in EU countries: new evidence using bounded unit root tests, Applied Economics Letters, 25(12), 2018, p. 807-810.

14 Caporale, G. M.; Gil-Alana, L.: The asymmetric behaviour of Spanish unemployment persistence, Economics Bulletin, 38(1) 2018, p. 98-104.

15 Gil-Alana, L. A. et al.: Long Memory in Turkish Unemployment Rates, Emerging Markets Finance and Trade, 55(1) 2019, p. 201-217.

16 Bošnjak, M. et al:: Long memory property of unemployment in Croatia, Theory and Applications in the Knowledge Economy, 2017, p. 727.

17 Skare, M.; Sinkovic, D.: Isolating long cycles in unemployment rates of Croatia using spectral modelling, Transformations in Business \& Economics, 2016, p. 15. 
ployment and long-term recovery. Highest level of persistence was present in Poland following Baltic countries, Slovakia and Czech Republic and the persistence was least present in Hungary and Slovenia. ${ }^{18}$ Finally, fractional integration was employed to examine hysteresis in 11 African countries (Zambia, Tanzania, South Africa, Senegal, Nigeria, Mauritania, Malawi, Kenya, Ghana, Ethiopia and Botswana) in the period 1960-2010. Results confirmed that unemployment had no mean reverting property. It is believed that the lack of recovery is a governed by the labor market rigidity. Endogenous shocks have permanent consequences emphasizing importance of the corrective measures. ${ }^{19}$

Application of the quantile regression approach developed by Koenker and Xiao avoided some of the weaknesses of other techniques in examining stationary. ${ }^{20,21}$ Considering the nonlinear patterns quantile auto regression allows for examination of mean reverting properties enabling analysis of endogenous shocks, their size, direction and persistence.

Using quantile unit root tests endogenous shocks in unemployment were examined for 12 OECD countries. Results demonstrate asymmetric adjustments. Strong negative shocks do not persist while strong positive shocks do persist. Therefore unemployment rises quickly and drops slowly. With asymmetric adjustments conventional unit root tests may not be able to confirm stationarity. For this type of patterns quantile regression approach is recommended. ${ }^{22}$ Only few more studies so far have applied this type of technique for unemployment hysteresis exploration. Two more studies examined unemployment in the USA and one examined the unemployment in 9 East European countries.

Results of the first USA unemployment study in the period from 1928-2014 was test dependent. Conventional unit root tests did not confirm the existence of unemployment hysteresis. Kolmogorov-Smirnov test also rejected the hysteresis hypothesis. Nevertheless quantile unit root tests confirmed the existence of hysteresis in $3^{\text {rd }}$ and $4^{\text {th }}$ quantile. ${ }^{23}$

18 Cuestas, J. C. et al.: A further investigation of unemployment persistence in European transition economies, Journal of Comparative Economics, 39(4) 2011, p. 514-532

19 Caporale, G. M.; Gil-Alana, L. A.: Unemployment in Africa: A Fractional Integration Approach, South African Journal of Economics, 86(1) 2018, p. 76-81.

20 Koenker, R.; Xiao, Z.: Unit Root Quantile Autoregression Inference, Journal of the American Statistical Association, 99(467) 2004, p. 775-787.

${ }_{21}$ Koenker, R.; Xiao, Z.: Quantile Autoregression. Journal of the American Statistical Association, 101:475, 2006, p. 980-990.

22 Lee, C. et al.: Asymmetric behavior of unemployment rates: Evidence from the quantile covariate unit root test, Japan and the World Economy, 28, 2013, p. 72-84.

23 Yushi, J.; Tsangyao, C.: Bring Quantile unit root test back in testing hysteresis in unemployment for the United States, Romanian Journal of Economic Forecasting, 19(1) 2016. 
USA unemployment study in the period 1976-2016 confirmed national unemployment hysteresis in periods of recession. Nineteen federal states confirmed hysteresis. Remaining federal states exhibited four types of behavior. Some states had mean reverting properties in almost all quantiles, some had hysteresis in the period of contraction and some confirmed hysteresis during expansion. $^{24}$

Finally, nine East European countries were tested using quantile unit root tests with and without considering structural break along Fourier function in the period from 2000-2016. According to monthly data asymmetries and hysteresis were confirmed only for Romania and Hungary. Other examined countries were Bulgaria, Czech Republic, Slovakia, Latvia, Lithuania, Poland and Russia. $^{25}$

This paper uses rather innovative approach in examination of endogenous shocks properties of the Croatian unemployment.

\section{METHODOLOGY AND DATA}

Seasonally adjusted quarterly unemployment data for the period 2000Q12018Q4 were obtained from Eurostat. Change in the level of Croatia's unemployment may be observed in Graph 1.

Graph 1 Quarterly rate of unemployment in Croatia in the period 2000Q12018Q4

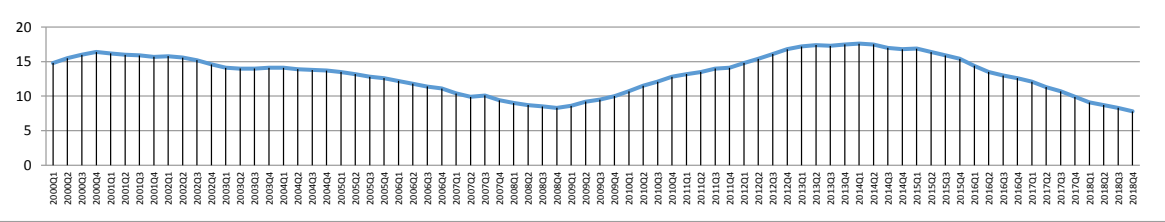

Source: https://ec.europa.eu/eurostat/databrowser/view/tipsun30/default/table?lang=en

24 Bahmani-Oskooee, M. et al.: Testing hysteresis effect in U.S. state unemployment: new evidence using a nonlinear quantile unit root test, Applied Economics Letters, 25(4) 2018, p. 249-253.

25 Xie, H. et al:: Revisit Hysteresis Unemployment in Eastern European Countries using Quantile Regression, Ekonomický časopis (Journal of Economics), 66(5) 2018. 
Quarterly rate of unemployment in Croatia in the period 2000Q1-2018Q4 exhibits cyclical properties. Unemployment rate in Croatia was rising from the beginning of the observed period reaching the first peak in the last quarter of 2000 $(16,4 \%)$. Later on the level of unemployment was decreasing until the global financial crisis in the last quarter of 2008. Since then, the unemployment is rising reaching the second peak in the first quarter of 2014 (17,6\%). Consequently entering the European Union and economic recovery (positive growth rates in 2015) unemployment continued to decrease after the first quarter of 2014. By the last quarter of 2018 the level of unemployment has reached 7,8\% (see Graph 1).

Before model estimations unemployment is tested for structural breaks. Since there was no evidence of structural breaks (see appendix 2) model variables are calculated according to the equation (1)

$$
d l k n c_{t}=l k n c_{t}-l \overline{\overline{(k n c)}}
$$

where:

$d l k n c_{t}-$ represents the log value of the quarterly unemployment rate in the period $t$ deducted by the log value of the quarterly unemployment rate mean,

$l k n c_{t}-\log$ value of the quarterly unemployment rate in period $\mathrm{t}$,

$l \overline{\overline{(k n c)}}-\log$ value of the quarterly unemployment rate mean

and according to the equation (2)

$$
f d l k n c_{t}=l k n c_{t}-l k n c_{t-1}
$$

where:

fdlknc $c_{t}$ change in the log value of the quarterly unemployment rate in period $\mathrm{t}$, $f_{k n c_{t}}-\log$ value of the quarterly unemployment rate in period $\mathrm{t}$

$l k n c_{t-1}-\log$ value of the quarterly unemployment rate in period $\mathrm{t}-1$.

Auto-regression model is defined according to the equation (3)

$$
d l k n c_{t}=\alpha+\sum_{i=1}^{n} \beta_{i} \cdot d l k n c_{t-i}+\varepsilon_{t}
$$

If the process is integrated order (1) shock would persist and if the process is integrated order (0) its impact would dissolve in time. ${ }^{26}$ When $\sum_{i=1}^{n} \beta_{i}<1$ null

26 Yushi, J.; Tsangyao, C.: Bring Quantile unit root test back in testing hysteresis in unemployment for the United States, Romanian Journal of Economic Forecasting, 19(1) 2016. 
hypothesis states that time series of unemployment is stationary and shocks dissolve. Otherwise when $\sum_{i=1}^{n} \beta_{i}=1$ alternative hypothesis states that shock will cause formation of new mean value of unemployment. Finally, according to information criteria number of lag selected equals 2 . Therefore auto-regression process is given by the equation (4)

$$
d l k n c_{t}=\alpha+\beta_{1} \cdot d l k n c_{t-1}+\beta_{1} \cdot d l k n c_{t-2}+\varepsilon_{t}
$$

where $\alpha$ represent intercept, $\beta_{i}$ auto-regression coefficients with lag $(i=1, \ldots$ $n)$ and $\varepsilon$ error terms.

Sum of the auto-regression coefficients $\sum_{i=1}^{n} \beta_{i}$ represent the measure of the persistence in the observed time series ( dlknc $_{t} /$ fdlknc $\left._{t}\right)$.

According to the methodology developed by Koenker and Xiao auto-regression process of the second order is defined by the equation (5)

$$
Q_{y_{t}}\left(\tau \mid y_{t-1,} y_{t-2,}\right)=\beta_{1}(\tau) \cdot y_{t-1}+\beta_{2}(\tau) y_{t-2}+\varepsilon(\tau)
$$

where $Q_{y_{t}}\left(\tau \mid y_{t-1}\right)$ represent $\tau$-quantile of the unemployment series, $\varepsilon(\tau)$ $\tau$-quantile of the error term $\varepsilon(\tau)$ therefore the endogenous shock, while $\beta(\tau)$ represent coefficient of the auto-regression variable dependent in quantile. Error term $\varepsilon(\tau)$ reflects the magnitude and direction of the endogenous shock while the sum of the coefficients $\beta_{1}(\tau)$ and $\beta_{2}(\tau)$ reflect its persistence.

Standard errors are calculated according to Hall and Sheather assuming local linearity of the conditioned quantile function. More about quantile auto-regression used in this paper could be found in the pioneer work of Koenker and Xiao. $^{27}$

\section{EMPIRICAL RESULTS}

Before further examination descriptive statistics for Croatian quarterly unemployment in the period 2000Q1-2018Q4 are summarized in Table 1.

27 Koenker, R.; Xiao, Z.: Unit Root Quantile Autoregression Inference, Journal of the American Statistical Association, 99(467) 2004, p. 775-787. 
Table 1. Quarterly rate of unemployment in Croatia in the period from 2000Q1 to $2018 Q 4$

\begin{tabular}{|c|c|c|c|c|c|c|}
\hline Average & Max & Min & Std.dev. & Asymmetry & Skewness & Jarque-Bera \\
\hline 13,27 & 17,6 & 7,8 & 2,83653 & $-0,5728$ & 2,1712 & 6,3321 \\
\hline$-0,093 *$ & $0,80 *$ & $-1,0 *$ & $0,45806 *$ & $0,2112^{*}$ & $2,3229 *$ & $1,9901 *$ \\
\hline
\end{tabular}

* $\log$ value of the quarterly unemployment in the period $t$ deducted by the log value of the quarterly unemployment mean

Source: Author's calculation

Average quarterly unemployment in the observed period 2000Q1-2018Q4 was $13,3 \%$. According to average rate Croatia is the $4^{\text {th }}$ country of EU with the highest rate of unemployment. Only Slovakia, Greece and Spain had a higher rate of unemployment respectively $13,8 \%, 15,6 \%$ and 15,9\%. (See Appendix 1b). Lowest level of the unemployment was 7,8\% and highest level of the unemployment was $17,6 \%$. Distribution has mild negative asymmetry $-0,2878$ and skewness 1,92587. Jarque Bera test result underlines deviations from the normal distributions advising quantile auto-regression approach. ${ }^{28}$ Change in the level of the unemployment on average (first differences) was $-0,093$. The most significant increase in the quarterly level of the unemployment was 0,8 and the most significant decrease in the quarterly level of the unemployment was $-1,0$. Distribution has mild positive asymmetry $(0,21112)$ and skewness 2,3229.

Following Table 2 contains estimates of unit root testing for quarterly unemployment data in Croatia in the period from 2000Q1 to 2018Q4 using conventional tests.

28 Blanchard, O.: Should We Reject the Natural Rate Hypothesis?. Journal of Economic Perspectives, 32(2) 2018, p. 97-120. 
Table 2. Unit root testing for the quarterly unemployment rate in Croatia in the period 2000Q1-2018Q4

\begin{tabular}{|l|c|c|c|c|}
\hline & $\begin{array}{c}\text { In levels } \\
\text { (trend and } \\
\text { constant) }\end{array}$ & $\begin{array}{c}\text { In levels } \\
\text { (constant) }\end{array}$ & $\begin{array}{c}\text { First } \\
\text { differences } \\
\text { (trend and } \\
\text { constant) }\end{array}$ & $\begin{array}{c}\text { First } \\
\text { differences } \\
\text { (constant) }\end{array}$ \\
\hline Name of the test & Test statistic & Test statistic & Test statistic & Test statistic \\
\hline ADF test & $-2,8363$ & $-2,8284$ & $-2,8258$ & $-2,7807$ \\
\hline Level of significance & $\begin{array}{c}\text { Critical } \\
\text { values }\end{array}$ & $\begin{array}{c}\text { Critical } \\
\text { values }\end{array}$ & $\begin{array}{c}\text { Critical } \\
\text { values }\end{array}$ & $\begin{array}{c}\text { Critical } \\
\text { values }\end{array}$ \\
\hline $1 \%$ & $-4,0906$ & $-3,5242$ & $-4,0868$ & $-3,5215$ \\
\hline $5 \%$ & $-3,4734$ & $-2,9023$ & $-3,4716$ & $-2,9012$ \\
\hline $10 \%$ & $-3,1639$ & $-2,5885$ & $-3,1629$ & $-2,5879$ \\
\hline Name of the test & Test statistic & Test statistic & Test statistic & Test statistic \\
\hline Phillips-Perron & $-0,9979$ & $-0,8770$ & $-2,7166$ & $-2,6655$ \\
\hline Level of significance & $\begin{array}{c}\text { Critical } \\
\text { values }\end{array}$ & $\begin{array}{c}\text { Critical } \\
\text { values }\end{array}$ & $\begin{array}{c}\text { Critical } \\
\text { values }\end{array}$ & $\begin{array}{c}\text { Critical } \\
\text { values }\end{array}$ \\
\hline $1 \%$ & $-4,0850$ & $-3,5203$ & $-4,0868$ & $-3,5215$ \\
\hline $5 \%$ & $-3,4708$ & 2,9006 & $-3,4716$ & $-2,9012$ \\
\hline $10 \%$ & $-3,1624$ & $-2,5876$ & $-3,1629$ & $-2,5879$ \\
\hline Name of the test & Test statistic & Test statistic & Test statistic & Test statistic \\
\hline KPSS & 0,1357 & 0,1469 & $-0,1682$ & $-0,2033$ \\
\hline Level of significance & $\begin{array}{c}\text { Critical } \\
\text { values }\end{array}$ & $\begin{array}{c}\text { Critical } \\
\text { values }\end{array}$ & $\begin{array}{c}\text { Critical } \\
\text { values }\end{array}$ & $\begin{array}{c}\text { Critical } \\
\text { values }\end{array}$ \\
\hline $1 \%$ & 0,2160 & 0,7390 & 0,2160 & 0,7390 \\
\hline $5 \%$ & 0,1460 & 0,4630 & 0,1460 & 0,4630 \\
\hline $10 \%$ & 0,1190 & 0,3470 & 0,1190 & 0,3470 \\
\hline
\end{tabular}

Source: Author's calculation

Augmented Dickey-Fuller test suggests that there is a unit root in time series of Croatian unemployment rate in levels and first differences according to $1 \%$ level of significance. Phillips-Perron test also suggests there is a unit root in time series of Croatian unemployment in levels and first differences according to $1 \%$ level of significance. Nevertheless, Kwiatkowski-Phillips-Schmidt-Shin test with the null hypothesis stating that the time series of the Croatian unemployment rate is stationary is not able to reject the null hypothesis either in levels or first differences according to $1 \%$ level of significance. Inconsistent results of conventional unit root tests may reflect non-linear properties of time series and quantile auto-regression approach is advisable for modelling this type of patterns. 
Following Table 3 contains quantile auto-regression estimates for the Croatian unemployment rate.

Table 3. Estimates of the quantile auto-regression for the Croatian quarterly unemployment rate

\begin{tabular}{|c|c|c|c|c|c|c|c|c|c|c|}
\hline $\mathbf{Q}(\tau)$ & $\alpha_{0}(\tau)$ & t-stat & $\mathbf{p}$ & $\alpha_{1}(\tau)$ & t-stat & $\mathbf{p}$ & $\alpha_{2}(\tau)$ & t-stat & $\mathbf{p}$ & $\alpha_{1}(\tau)+\alpha_{2}(\tau)$ \\
\hline 0,1 & $-0,02658$ & $-2,59$ & 0,01 & 1,91755 & 7,83 & 0,00 & $-0,90970$ & $-3,58$ & 0,00 & 1,00785 \\
\hline 0,2 & $-0,01846$ & $-4,60$ & 0,00 & 1,81873 & 17,40 & 0,00 & $-0,80733$ & $-7,73$ & 0,00 & 1,01140 \\
\hline 0,3 & $-0,01077$ & $-3,46$ & 0,00 & 1,80257 & 21,52 & 0,00 & $-0,80193$ & $-9,33$ & 0,00 & 1,00064 \\
\hline 0,4 & $-0,00781$ & $-2,25$ & 0,03 & 1,79680 & 21,21 & 0,00 & $-0,80315$ & $-9,03$ & 0,00 & 0,99365 \\
\hline 0,5 & $-0,00262$ & $-0,81$ & 0,42 & 1,80665 & 23,11 & 0,00 & $-0,82510$ & $-9,99$ & 0,00 & 0,98155 \\
\hline 0,6 & 0,00243 & 0,79 & 0,43 & 1,86125 & 23,57 & 0,00 & $-0,88954$ & $-10,82$ & 0,00 & 0,97171 \\
\hline 0,7 & 0,00779 & 2,06 & 0,04 & 1,85638 & 18,39 & 0,00 & $-0,89752$ & $-8,78$ & 0,00 & 0,95886 \\
\hline 0,8 & 0,01303 & 3,43 & 0,00 & 1,81832 & 20,45 & 0,00 & $-0,85914$ & $-10,35$ & 0,00 & 0,95918 \\
\hline 0,9 & 0,02263 & 2,54 & 0,01 & 1,69958 & 8,34 & 0,00 & $-0,74445$ & $-3,43$ & 0,00 & 0,95513 \\
\hline
\end{tabular}

Source: Author's calculation

Estimates of the quantile auto-regression confirm persistence and asymmetric properties of the unemployment rate in Croatia. Strong negative shocks (decrease of the rate of unemployment) are highly persistent and moderate/mild negative shocks are less persistent. Positive shocks have even less persistence. Decreasing level of the unemployment rate has the highest level of persistence while increasing level of the unemployment rate persist but relatively less. Accordingly, depending on direction of the endogenous shock, rate of the unemployment has asymmetric properties.

Endogenous shocks in Croatian unemployment tend to persist. Consequently strong positive shocks result in higher average level of unemployment. This information may be interesting for policy creators considering to alleviate negative effects of endogenous shocks of unemployment.

Estimates given in Table 3 are illustrated in the Appendix 3. Since the sum of auto-regression coefficients are more than 1 for strong positive shocks, quantile auto-regression estimates are further calculated for the speed of adjustment of the unemployment rate (first differences). Accordingly, Table 4 contains quantile auto-regression estimates for the Croatian unemployment rate speed of adjustment (first differences). 
Table 4. Estimates of the quantile auto-regression for the Croatian unemployment speed of adjustment rate (first differences)

\begin{tabular}{|c|c|c|c|c|c|c|c|c|c|c|}
\hline $\mathbf{Q}(\tau)$ & $\alpha_{0}(\tau)$ & t-stat & $\mathbf{p}$ & $\alpha_{1}(\tau)$ & t-stat & $\mathbf{p}$ & $\alpha_{2}(\tau)$ & t-stat & $\mathbf{p}$ & $\alpha_{1}(\tau)+\alpha_{2}(\tau)$ \\
\hline 0,1 & $-0,02526$ & $-5,36$ & 0,00 & 0,42525 & 1,61 & $\mathbf{0 , 1 1}$ & 0,61614 & 2,41 & 0,02 & 1,04139 \\
\hline 0,2 & $-0,01968$ & $-5,72$ & 0,00 & 0,46650 & 2,65 & 0,01 & 0,47621 & 2,37 & 0,02 & 0,94271 \\
\hline 0,3 & $-0,01384$ & $-4,23$ & 0,00 & 0,54367 & 4,29 & 0,00 & 0,32026 & 2,99 & 0,00 & 0,86393 \\
\hline 0,4 & $-0,00915$ & $-2,94$ & 0,00 & 0,59991 & 3,55 & 0,00 & 0,16550 & 1,05 & $\mathbf{0 , 3 0}$ & 0,76541 \\
\hline 0,5 & $-0,00478$ & $-1,45$ & 0,15 & 0,67096 & 8,26 & 0,00 & 0,11739 & 1,23 & $\mathbf{0 , 2 2}$ & 0,78835 \\
\hline 0,6 & 0,00205 & 0,55 & 0,59 & 0,76811 & 8,48 & 0,00 & 0,06681 & 0,64 & $\mathbf{0 , 5 2}$ & 0,83492 \\
\hline 0,7 & 0,00806 & 2,20 & 0,03 & 0,75447 & 6,70 & 0,00 & 0,13229 & 1,09 & $\mathbf{0 , 2 8}$ & 0,88676 \\
\hline 0,8 & 0,01210 & 2,73 & 0,01 & 0,80423 & 7,13 & 0,00 & 0,10900 & 0,83 & $\mathbf{0 , 4 1}$ & 0,91323 \\
\hline 0,9 & 0,02262 & 3,34 & 0,00 & 0,90732 & 3,33 & 0,00 & $-0,04672$ & $-0,17$ & $\mathbf{0 , 8 7}$ & 0,86060 \\
\hline
\end{tabular}

Source: Author's calculation

Estimates of the quantile auto-regression confirm the persistence in the speed of adjustment of the Croatian unemployment rate. Strong negative shocks depended only on the second order coefficient. Strong negative shocks in the speed of adjustment of the unemployment rate persist. Moderate negative shocks depend on first and second order coefficients and also persist. Mild negative shocks and positive shocks depend only on the first order coefficient and shocks persist relatively less. To summarize, speed of the adjustment of the unemployment rate in Croatia will depend on the previous periods and any change will persist. Estimates given in Table 4 are illustrated in the Appendix 4.

Persistence in the endogenous shock of unemployment may result from the specific properties of the labor market. Labor market may vary in between structuralist models and hysteresis. In the case of European countries labor markets are relatively rigid ${ }^{29}$. Once permanently employed people are rarely laid off and when they are they tend to stay unemployed especially when coupled with the economic downturn. ${ }^{30}$ Although most of the Croatian unemployment is attributed to less educated people unemployment of highly educated people has raised even more quickly in the period 2008-2015. ${ }^{31}$ Croatian labor market is fragmented, inappropriately structured and has unfavorable dyna-

29 Caporale, G. M.; Gil-Alana, L. A.: Unemployment in Africa: A Fractional Integration Approach, South African Journal of Economics, 86(1) 2018, p. 76-81.

30 Bejaković, P.: Mjere za ublažavanje dugotrajne nezaposlenosti u Hrvatskoj. Političke analize, 9 (33-34) 2018, p. 36-43.

31 Obadić, A.: Nezaposlenost mladih I usklađenost obrazovnog sustava s potrebama tržišta rada, Ekonomska misao i praksa, (1) 2017, p. 129-150. 
mics. Relatively high level of unemployment may be attributed to demography, insufficient flexibility, pension system and discrepancies between education and labor demand..$^{32}$ These properties represent important foundation for policy makers aiming to solve the problem of relatively high level of unemployment in Croatia.

\section{CONCLUSION}

According to the results of the empirical research in this paper there are several conclusions. Unemployment in Croatia belongs to EU countries with the highest rate of unemployment. Furthermore, unemployment in Croatia has asymmetric properties and inherent hysteresis. Endogenous shocks have longterm consequences making corrective policy very important in reducing negative effects of rising unemployment. Absence of adequate policy aiming to alleviate discrepancies in the labor market may result in long-term higher rates of unemployment with further drag to the national economy. Results of the previous research and this paper emphasize the importance of policy measures. Corrective policy is often inhibited by the lack of resources but careful selection of measures may compensate for this constraint.

\section{APPENDIX 1}

a) Unemployment rate for European countries, 2000Q1-2018Q4, quarterly data, seasonally adjusted

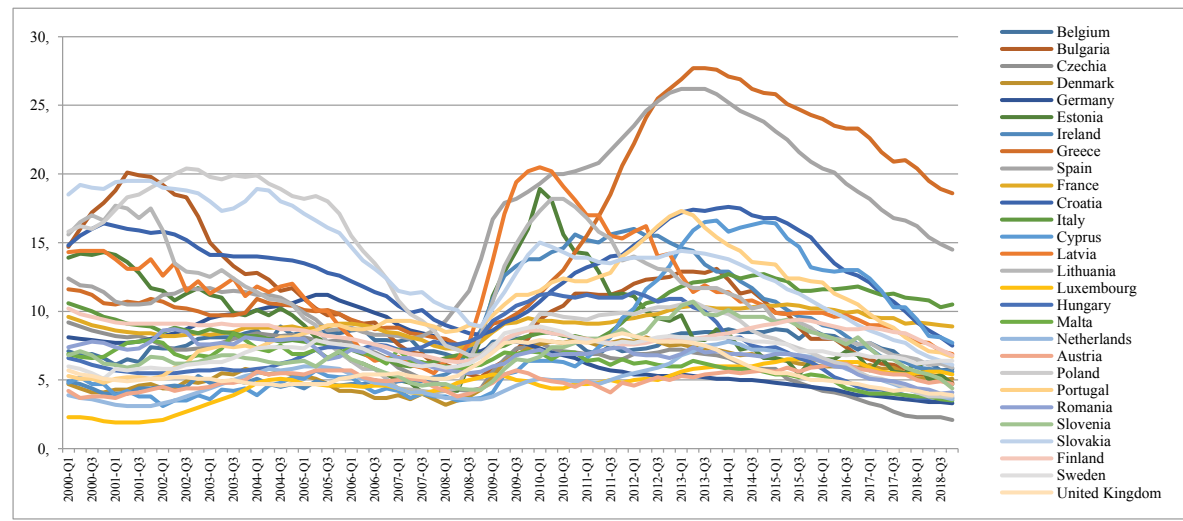

Source: https://ec.europa.eu/eurostat/databrowser/view/tipsun30/default/table?lang=en

32 Bošnjak, M. et al.: Long memory property of unemployment in Croatia, Theory and Applications in the Knowledge Economy, 2017, p. 727. 
b) Average unemployment rate for the European countries, 2000Q12018Q4, quarterly data, seasonally adjusted

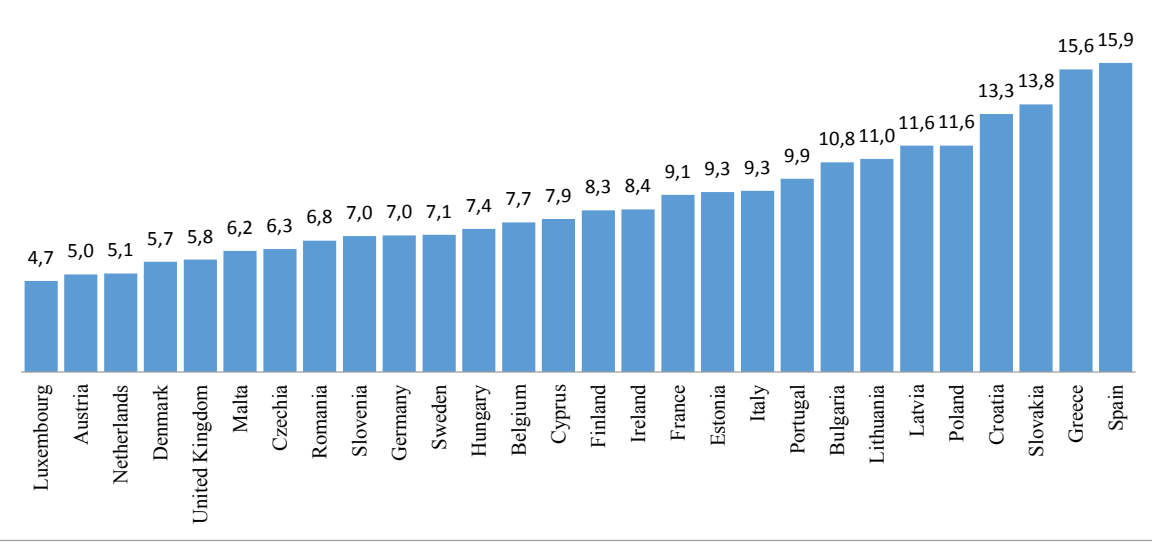

Source: https://ec.europa.eu/eurostat/databrowser/view/tipsun30/default/table?lang=en

\section{APPENDIX 2}

a) Structural break detection in quarterly unemployment in Croatia in the period2000Q1-2018Q4, axis $x$ - time, axis $y$ - log quarterly unemployment rate deducted by average

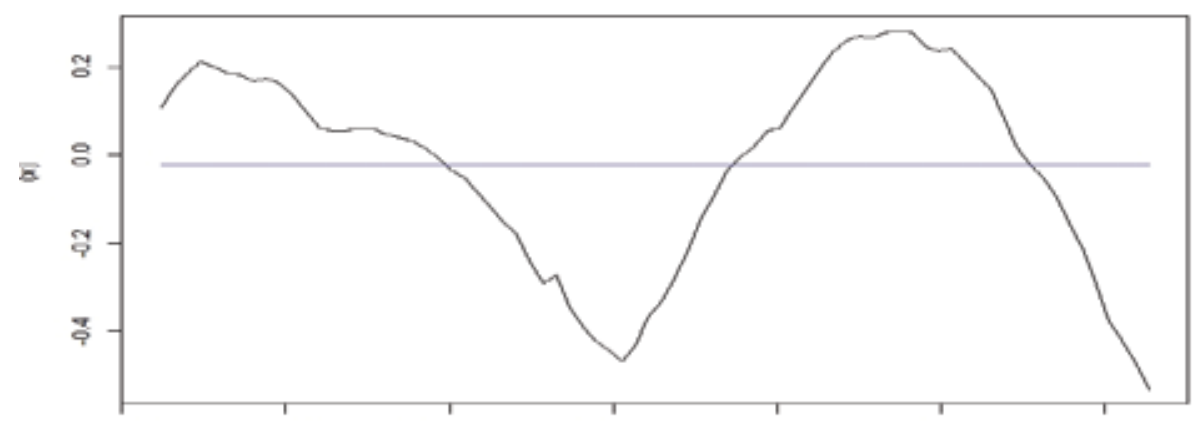

Source: Author's calculation 
b) Structural break detection in adjustment rate of quarterly unemployment in Croatia in the period2000Q1-2018Q4, axis $x$ - time, axis $y$ adjustment rate of quarterly unemployment

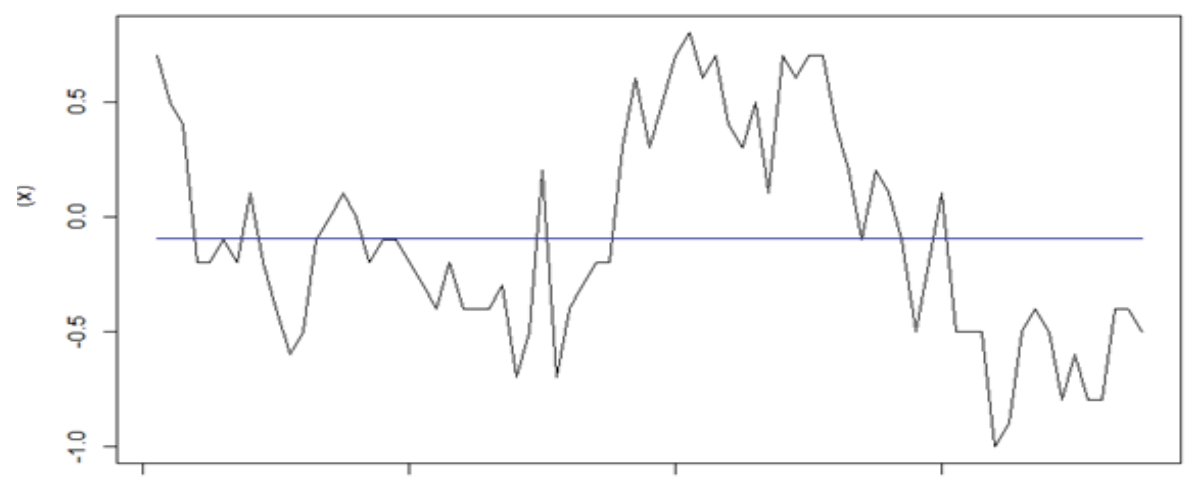

Source: Author's calculation

\section{APPENDIX 3.}

Graphical illustration of quantile auto-regression coefficients for speed of adjustment of quarterly unemployment in Croatia in the period 2000Q1-2018Q4: intercept $(\alpha)$, auto-regression coefficients $\beta_{1} \& \beta_{2}$ across quantiles, axis $\mathrm{x}-$ quantiles, axis $y-$ value of the coefficient
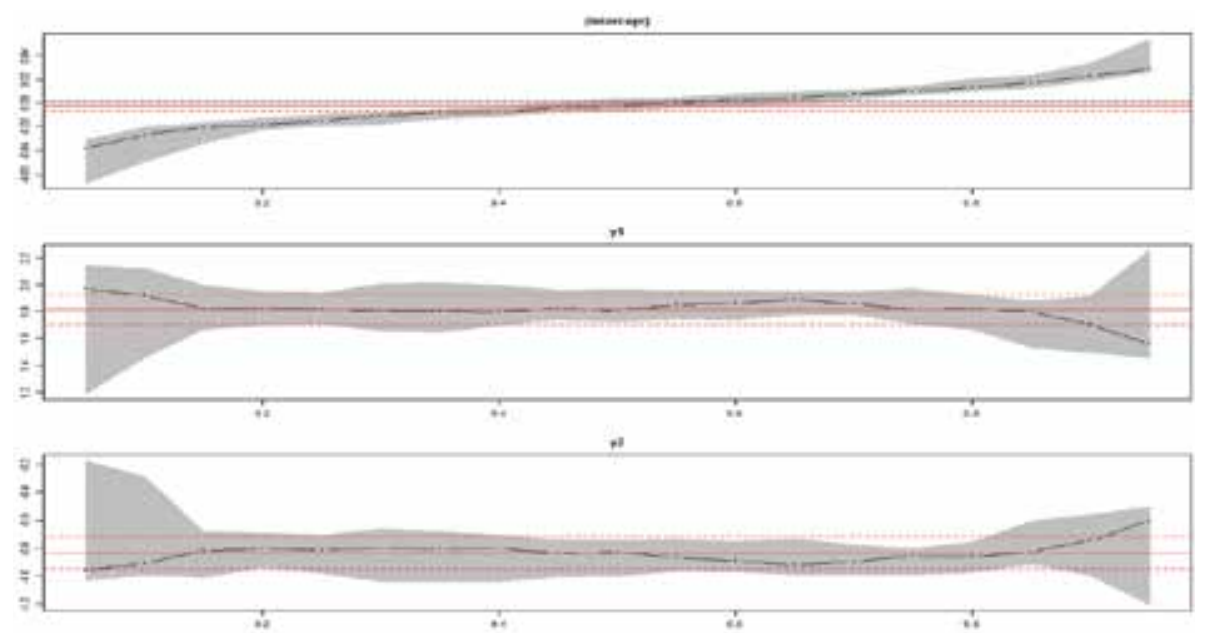

Source: Author's calculation 


\section{APPENDIX 4}

Graphical illustration of quantile auto-regression coefficients for quarterly unemployment in Croatia in the period 2000Q1-2018Q4: intercept $(\alpha)$, auto-regression coefficients $\beta_{1} \& \beta_{2}$ across quantiles, axis $\mathrm{x}$-quantiles, axis $\mathrm{y}-$ value of the coefficient
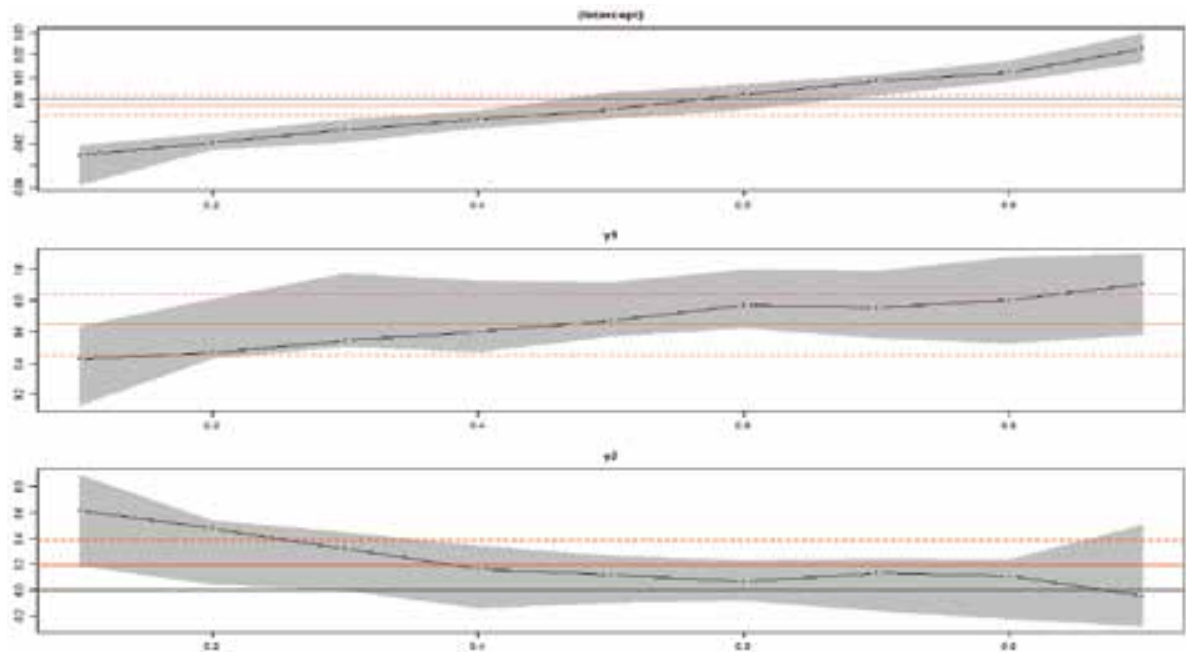

Source: Author's calculation

\section{LITERATURE}

1. Akdogan, K. (2017). Unemployment hysteresis and structural change in Europe, Empir Econ, 53(4), 1415-1440.

-DOI: https://doi.org/10.1007/s00181-016-1171-8

2. Albulescu, C. T. \& Tiwari, A. K. (2018). Unemployment persistence in EU countries: new evidence using bounded unit root tests. Applied Economics Letters, 25(12), 807-810.

-DOI: https://doi.org/10.1080/13504851.2017.1368979

3. Bahmani-Oskooee, M., Chang, T. \& Ranjbar, O. (2018). Testing hysteresis effect in U.S. state unemployment: new evidence using a nonlinear quantile unit root test. Applied Economics Letters, 25(4), 249-253.

-DOI: https://doi.org/10.1080/13504851.2017.1316477

4. Bečić, M. (2014). Preobrazovanost na tržištu rada Republike Hrvatske. Privredna kretanja i ekonomska politika, 23 (1 (134)), 9-36. Downloaded from: https://hrcak.srce.hr/125491 
5. Bejaković, P. (2018). Mjere za ublažavanje dugotrajne nezaposlenosti u Hrvatskoj. Političke analize, 9 (33-34), 36-43. Downloaded from: https://hrcak.srce. $\mathrm{hr} / 205960$

6. Blanchard, O. (2018). Should We Reject the Natural Rate Hypothesis?. Journal of Economic Perspectives, 32(2), 97-120.

-DOI: http://dx.doi.org/10.1257/jep.32.1.97

7. Bošnjak, M., Bilas, V. \& Franc, S. (2017). Long memory property of unemployment in Croatia. Theory and Applications in the Knowledge Economy, 727.

8. Botrić, V. (2012). NAIRU estimates for Croatia. Zbornik radova Ekonomskog fakulteta u Rijeci, 30 (1), 163-180. Downloaded from: https://hrcak.srce.hr/83355

9. Caporale, G. M. \& Gil-Alana, L. (2018)a. The asymmetric behaviour of Spanish unemployment persistence. Economics Bulletin, 38(1), 98-104. Downloaded from: http://www.accessecon.com/Pubs/EB/2018/Volume38/EB-18-V38-I1-P10. pdf

10. Caporale, G. M. \& Gil-Alana, L. A. (2018)b. Unemployment in Africa: A Fractional Integration Approach. South African Journal of Economics, 86(1), 76-81.

-DOI: https://doi.org/10.1111/saje.12178

11. Cuestas, J. C., Gil-Alana, L. A. \& Staehr, K. (2011). A further investigation of unemployment persistence in European transition economies. Journal of Comparative Economics, 39(4), 514-532.

-DOI: http://dx.doi.org/10.1016/j.jce.2011.09.002

12. Dursun, G. (2017). Unemployment Hysteresis in Central and Eastern European Countries: Further Evidence from Fourier Unit Root Tests, EconWorld2017@ Rome Proceedings, Rome, Italy, Downloaded from: https://rome2017.econworld. org/papers/Dursun_Unemployment.pdf

13. Furuoka, F. (2017)a. A new test for analysing hysteresis in European unemployment. Applied Economics Letters, 24(15), 1102-1106.

-DOI: http://dx.doi.org/10.1080/13504851.2016.1257209

14. Furuoka, F. (2017)b. Mean reversion in unemployment: New findings from the Baltic tigers. Technological and Economic Development of Economy, 23(3), 462482 .

-DOI: http://dx.doi.org/10.3846/20294913.2015.1070769

15. Gil-Alana, L. A., Ozdemir, Z. A. \& Tansel, A. (2019). Long Memory in Turkish Unemployment Rates. Emerging Markets Finance and Trade, 55(1), 201-217.

-DOI: https://doi.org/10.1080/1540496X.2018.1425837

16. Koenker, R. \& Xiao, Z. (2004). Unit Root Quantile Autoregression Inference. Journal of the American Statistical Association, 99(467), 775-787. Retrieved from http://www.jstor.org/stable/27590447

-DOI: https://doi.org/10.1198/016214504000001114 
17. Koenker, R. \& Xiao,Z. (2006). Quantile Autoregression. Journal of the American Statistical Association, 101:475, 980-990, -DOI: https://doi.org/10.1198/016214506000000672

18. Kroft, K., Lange, F. \& Notowidigdo, M. J. (2013). Duration Dependence and Labor Market Conditions: Evidence from a Field Experiment. The Quarterly Journal of Economics, Volume 128, 3(1), 1123-1167,

-DOI: https://doi.org/10.1093/qje/qjt015

19. Lee, C., Hu, T., Li, P. \& Tsong, C. (2013). Asymmetric behavior of unemployment rates: Evidence from the quantile covariate unit root test. Japan and the World Economy, 28, 72-84.

-DOI: doi:10.1016/j.japwor.2013.08.002

20. Li, J. P., Ranjbar, O. \& Chang, T. (2017). Unemployment hysteresis in PIIGS countries: a new test with both sharp and smooth breaks. The Singapore Economic Review, 62(05), 1165-1177.

-DOI: http://dx.doi.org/10.1142/S0217590815500782

21. Marjanovic, G. \& Mihajlovic, V. (2014). Analysis of Hysteresis in unemployment rates with structural breaks: the case of selected European countries. Inzinerine Ekonomika-Engineering Economics, 25(4), 378-386.

-DOI: http://dx.doi.org/10.5755/j01.ee.25.4.5263

22. Meng, M., Strazicich, M. C. \& Lee, J. (2017). Hysteresis in unemployment? Evidence from linear and nonlinear unit root tests and tests with non-normal errors. Empirical Economics, 53(4), 1399-1414.

-DOI: http://dx.doi.org/10.1007/s00181-016-1196-z

23. Obadić, A. (2017). Nezaposlenost mladih I usklađenost obrazovnog sustava s potrebama tržišta rada. Ekonomska misao i praksa, (1), 129-150. Downloaded from: https://hrcak.srce.hr/183552

24. Obradović, S., Ristić, L. \& Lojanica, N. (2018). Are unemployment rates stationary for SEE10 countries? evidence from linear and nonlinear dynamics. Zbornik Radova Ekonomskog Fakulteta u Rijeci, 36(2), 559-583.

-DOI: doi:10.18045/zbefri.2018.2.559

25. Skare, M. \& Sinkovic, D. (2016). Isolating long cycles in unemployment rates of Croatia using spectral modelling. Transformations in Business \& Economics, 15. Downloaded from: https://fet.unipu.hr/_download/repository/10_Skare Sinkovic_CR_final.pdf

26. Xie, H., Chang, T., Grigorescu, A. \& Hung, K. (2018). Revisit Hysteresis Unemployment in Eastern European Countries using Quantile Regression. Ekonomický časopis (Journal of Economics), 66(5).

27. Yushi, J. \& Tsangyao, C. (2016). Bring Quantile unit root test back in testing hysteresis in unemployment for the United States. Romanian Journal of Economic Forecasting, 19(1). http://rjef.ro/ojs302/index.php/rjef/article/view/38 